\title{
Attitude of crop farmers towards e-wallet platform of the Growth Enhancement Support Scheme for input delivery in Oke-Ogun area of Oyo state
}

\author{
O. S. Fadairo ${ }^{1}$, Nathaniel S. Olutegbe ${ }^{2}$, Adewale M Tijani ${ }^{3}$
}

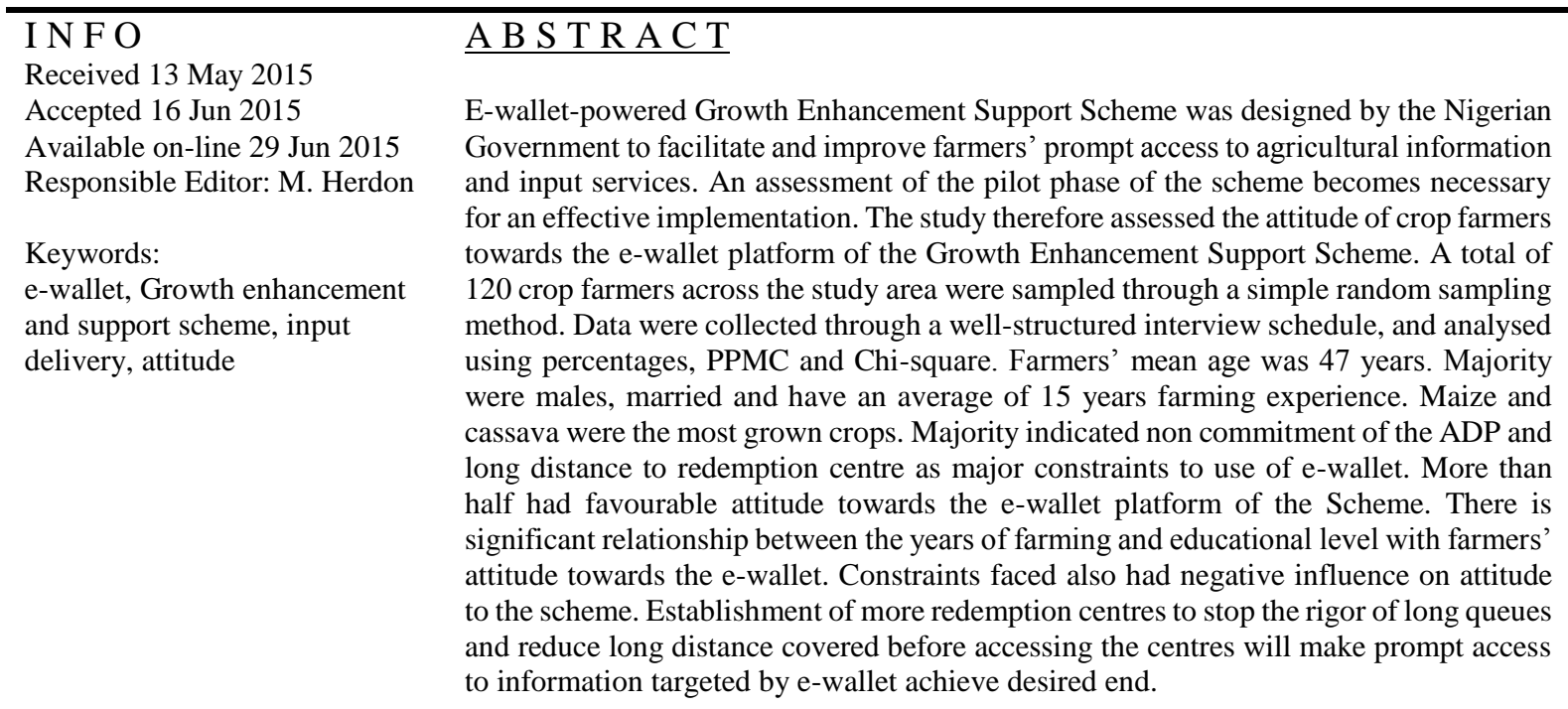

\section{Introduction}

In many developing countries, efforts at agricultural progress have failed because of inadequate attention to one or more components of successful policy (Jagdish 1996). That has over the years reduced agriculture revenue generation. Pulitzer (2012) reported that in Nigeria, Africa's most populous country, a legacy of sharp practices and an economy based primarily on oil exports has left the agricultural sector significantly weakened and millions of Nigerians hungry. Adeshina (2013) also posited that Nigeria's development efforts have over the years been characterized by lack of continuity, consistency and commitment to agreed policies, programs and projects as well as an absence of a longterm perspective. The culminating effect has been growth and development of the Nigerian economy without a concomitant improvement in agricultural system in Nigeria.

Ogundari and Ojo (2007) in Adebo (2014) equally observed that despite various efforts geared towards agricultural development, it has been estimated that $65 \%$ of Nigerians are living with hunger as food production growth is still as low as $2.5 \%$ per annum, while food demand have been growing at the rate of $2.8 \%$ per annum. There is high incidence of poverty among participants in agriculture, who are mostly rural based. In relation with GDP, the share of the agricultural sector has been less than 45\% since 1986 (CBN, 2003). Another factor contributing to this discouraging trend is the fact that agriculture in Nigeria is dominated by small scale farmers, who, in addition to low level of education, maintain low level of contact with extension services, low input, and poor advisory service. Policy inconsistencies and too much emphasis on production without due consideration to other value chain

\footnotetext{
${ }^{1}$ O. S. Fadairo

Dept of Agricultural Extension and Rural Development, University of Ibadan, Ibadan, Nigeria

dairom2@yahoo.com

2 Nathaniel S. Olutegbe Mail

Dept of Agricultural Extension and Rural Development, University of Ibadan, Ibadan, Nigeria

siji004u@yahoo.com

${ }^{3}$ Adewale M Tijani

dairom2@yahoo.com
} 
requirement have been identified as often responsible for the worsening scenarios. Corroborating this, Idachaba (2013) also posited that the dismal performance of the agricultural sub-sector in Nigeria is largely due to a number of factors among which are corruption and policy summersault. For instance, it was documented that between 1977 and 1996, the Federal Government implemented an annual programme of fertilizer procurement and distribution nationwide. In 1997, the fertilizer sub-sector was abruptly liberalized without a proper transition plan in place to encourage the organized private sector fill the gap left by government (FMAWR\&D, 2000). Fertilizer application then went down from a peak of 1.2 million tons in 1992 to a paltry 56,706 metric tons in 1997. Two years later; in 1999, subsidy was again re-introduced at a level of $25 \%$ and continued till year 2010 under the Fertilizer Market Stabilization Programme (FMSP). However, there were evidences that only $11 \%$ of the subsidized fertilizer actually reached the small holder farmers for which it was intended (FMARD, 2012).

The need for a holistic transformation of the Nigerian State has necessitated a strategy that gives cognizance to Growth Enhancement Support Scheme (GESS). The scheme was introduced in May 2012, as a pilot project in 36 states and the Federal Capital Territory. Being powered by the e-wallet approach, the scheme aims at achieving the set goals of overcoming the many difficulties confronting the agricultural sector in Nigeria and ensuring availability of fertiliser, seeds and other inputs to farmers as timely as possible. This is with the understanding that the corruption which has been the bane of agricultural development in Nigeria will be better tackled if and when farmers can directly access the government through their mobile phones. An e-wallet has thus been defined as an efficient and transparent electronic device system that makes use of vouchers for the purchase and distribution of agricultural inputs (Ezeh, 2013, Adesina, 2013).

The e-wallet approach is designed for smallholder farmers, who appear the most hit and vulnerable by the impropriety in the fertilizer and other input sector of the Agriculture Ministry. The criteria for farmer's participation include: farmers being above 18 years old; have participated in a survey authorized by the government to capture farmers personal detailed information; must own a cell phone with a registered SIM card and have at least sixty naira credit in the cell phone. The fulfilment of these conditions guarantees the issuance of an e-wallet voucher to the farmer. The voucher is used to redeem fertilizers, seeds and other agricultural inputs from agro-dealers at half the cost (Signal Alliance, 2014). Adebo (2014) further highlighted that for an agro input dealer to participate in the programme, he/she must own a cell phone with a registered SIM card, understand the process of using e-wallets, and attend training programmes designed for the project. The agro dealers are required to conduct honest business and guide against fraud; choose and prepare a location for the business transaction; provide storage facilities and be available at the appropriate time to attend to farmers' needs. Other prominent personalities in the scheme are the helpline personnel and redemption supervisors. Each state Agricultural Development Project (ADP) supplied the helpline staffs, and about 3-5 helpline staffs are assigned to each of the Local Government Area. The helpline staff and supervisors connect to the farmers on a daily basis to attend to their needs. The redemption supervisor helps in verifying farmer's identity as well as a farmer's code in the text message received by the farmer, and then compares it with the name and code listed in the farmers register which the supervisor received from the cellular. The subsidized farm inputs are delivered directly to farmers through their mobile phones. The project is expected to provide direct linkage between the farmers and the government. This will enable the government to disseminate valuable information to the farmers, thus ensuring farmers' progress (Ezeh, 2013). The system ensures the involvement of the private sector in agricultural input supply (NAN, 2012). According to the Federal Ministry of Agriculture and Rural Development (2011), about 14 million farmers have registered for the scheme throughout the federation. Inputs have been distributed in along seasonal production cycles to farmers for their needs and interest, for which the programme have been designed primarily.

Achieving the set goals of the GESS however requires having inputs in the form of a feedback from the primary beneficiary (farmers) on the pilot phase recently concluded before full implementation ensues. This is because sustainability of any programme and the success of similar programmes in the future cannot be divorced from the attitudinal disposition of the target beneficiaries. It is equally important to ascertain how the use of ICTs in the form of e-wallet as introduced by the federal ministry of Agriculture can be an effective tool in transforming the national agriculture, which has been anchored 
by the Agricultural transformation Agenda (ATA) of the federal government. It is against this background that this study has been designed to access the attitude of crop farmers towards the e-wallet platform of the GESS for input delivery in Oke-Ogun area of Oyo state.

The following specific objectives were achieved in the study: to

1. To identify the constraints to use of the e-wallet platform of the GESS

2. To ascertain farmers' attitude to e-wallet components of the GESS in the study area.

The following research hypotheses stated were also tested.

Ho1: There is no significant relationship between the farmers' socio economic characteristics and their attitude towards the use of e-wallet for accessing agricultural inputs.

Ho2: There is no significant relationship between respondents' constraints faced and their attitudes to the use of e-wallet for accessing agricultural inputs.

\section{Methodology}

The study was carried out in Oke-Ogun area of Oyo State. The area is located within the Guinea Savannah Zone. It shares border with Kwara, Niger, Ogun and Osun states, as well as Niger Republic (a neighbouring country). The area is recognized as the 'food basket' of the Southwestern Nigeria, having an annual rainfall ranging between $700-1100 \mathrm{~mm}$. The landmass of Oke-Ogun is about 13,537 Sq. Km. This is about $60 \%$ of the total land mass of the present Oyo State. The people are Yorubas and the main economic activities include: farming, hunting, fishing, food processing, transportation and craft businesses. Most farm families reside in the various settlements abounding in the villages and farmers still adopt traditional cultivation methods. Although there is a limited level of infrastructural and institutional development in the study area, GSM services is wide-spread across the entire area mainly provided by the MTN, Globacom, Etisalat and Airtel GSM companies. The common food crops grown in the area include yam, cassava, maize, vegetables, melon, guinea corn, pawpaw, water melon, plantain, banana, orange, mango, cashew cowpea and groundnut. Farmers still make use of traditional tools such as cutlass, hoe, axe, and so on.

A multistage sampling procedure was used to select respondents for this study. There are ten local government areas in the study area. Five LGAs were randomly selected (Atisbo, Iseyin, Itesiwaju, Iwajowa, Irepo) representing 50\% of the Oke-ogun area. A representative 50\% was considered good enough since the all the ten LGAs in the study area share the same characteristics in terms of Agricultural Extension Programme (ADP) structure in the state. Sangotegbe et al. (2012) sampled 20\% of the LGA in a study carried out in the same area. A list of all farmers registered with the ADP was obtained for each LGA and $10 \%$ of the farmers on this list was randomly sampled and selected for the study, giving a total of 120 sampled farmers. However, only 118 research instruments were used for analysis as two were not properly filled giving a return rate of $98.3 \%$. The population of study comprised of all crop farmers, and data were obtained with the aid of a well-structured interview schedule.

Attitude to the e-wallet platform was measured by presenting respondents with a list of statements that bother on the e-wallet platform of the GESS. This was measured on a 5-point rating scale, of strongly agree (SA), agree (A), undecided (U), disagree (D) and strongly disagree (SD). Scores of 5, 4, 3,2 , and 1 were awarded to positive statements from strongly disagree respectively and the reverse for negative statements. Mean score was computed from the respondents' attitudinal scores, and used as a benchmark for categorising respondents into having favourable and unfavourable attitudes. Respondents reacted to the listed constraints on a three-point scale of severe constraint, Mild constraint and not a constraint. Scores of 0,1 and 2 were assigned respectively. The mean score for each constraint was calculated and was used to rank them in order of severity.

Reliability of the research instrument was carried out as the scale developed for each variable was presented to experts in the field of Agricultural Extension and Rural Development, University of Ibadan, Nigeria for content and construct validity. A total of 30 pre-test instruments were administered on 20 respondents, in Ido local Government area of Oyo state. Using the statistical package for Social Science (SPSS), version 16, a reliability analysis was carried out. Split-half method was used for data analysis and $\mathrm{r}=0.75$ implied the instrument was reliable, after which the instrument was multiplied for the main 
data collection. Interview schedule was manually administered on all respondents for the study. Data analysis was carried out with the use of SPSS Version 16, Microsoft Excel (2010). Mean, frequency counts and percentages were used to describe the data by SPSS, while the Microsoft Excel (2010) was used to draw bar chat (Figure 1). The hypotheses were also tested with the use of Chi-square and Pearson Product Moment Correlation, using the SPSS.

\section{Results and discussion}

\section{Socio-economic characteristics of respondents}

Table 1 shows that $26.3 \%$ were within the age bracket of $41-50$ years, while $24.6 \%$ were within the age bracket of 51-60. This implies that majority (83.9\%) of the respondents were in their active age (2059) and this is in line with the work of Akinbile and Odebode (2002) which states that the population within the age group of 16-55 years constitute the active workforce in Nigeria. Furthermore, it can be inferred from Table 1. that the population of youths is low as only $11 \%$ of the respondents were within this range; Rural-urban migration is prevalent within this age range as most of the youths move to urban areas in search of better livelihood. This could mean loss of labour for agricultural activities in rural areas.

Table 1 further reveals that $68.6 \%$ were male, while $31.4 \%$ of the respondents were female. This implies that male participation in agricultural production in the study area is more pronounced than that of female. Also, $75.4 \%$ were married. This further confirms the existence of strong family/marriage ties among rural dwellers. According to Akinbile (2007), that marriage confers responsibility, there is the need to increase their productivity levels by improving their access to inputs, through such platforms like the e-wallet.

Findings further shows (Table 1.) that $34.7 \%$ of the respondents attended secondary school, while $32.2 \%$ had primary school education and $24.6 \%$ were graduates of tertiary institutions. The basic objective of any form of education is to impact knowledge which would influence a change in attitude, skills, or knowledge. It therefore implies that crop farmers in the study area will not have much problems making use of the e-wallet platform for accessing inputs for improved agricultural productivity in the study area.

As shown in the Table $173.7 \%$ of the respondents had 2-5\% hectares of farmland, while $22.9 \%$ had less than 1 hectare, and 2.5\% had up to 6-9 hectares. This establishes the fact that, Nigeria farmers are small scaled Such intervention as the e-wallet is necessary, as it can help improve the status of the farmers in the area, guaranteeing timely access to fertilizer, seeds and other essential agricultural inputs.

Table 1. Distribution of respondents by personal characteristics

\begin{tabular}{llrl}
\hline Personal Characteristics & Frequency (f) & \% & Mean \\
\hline Age (Years) & & & $\mathbf{4 7}$ \\
$21-30$ & 13 & 11.0 & \\
$31-40$ & 26 & 22.0 & \\
$41-50$ & 31 & 26.3 & \\
$51-60$ & 29 & 24.6 & \\
60 Above & 19 & 16.1 & \\
Sex & & & \\
Male & 81 & 68.6 & \\
Female & 37 & 31.4 & \\
Marital Status & & & \\
Single & 11 & 9.3 & \\
Married & 89 & 75.4 & \\
Widowed & 12 & 10.2 & \\
Divorced & 6 & 5.1 & \\
Educational & & & \\
Primary & 38 & 32.2 & \\
Secondary & 41 & 34.7 &
\end{tabular}




$\begin{array}{lrrr}\text { Tertiary } & 29 & 24.6 & \\ \text { Others } & 10 & 8.5 & \mathbf{1 5} \\ \text { Years of Farming } & & 39.8 & \\ \text { Less than 10yrs } & 47 & 35.6 & \\ 11-20 & 42 & 17.8 & \\ 21-30 & 21 & 5.1 & \\ 31-40 & 6 & 1.7 & \\ \text { Greater than 41 } & 2 & & \mathbf{3} \\ \text { Size Of farm land cultivated } & & 22.9 & \\ \text { Less or equal to 1 } & 27 & 73.7 & \\ \text { 2-5 } & 87 & 2.5 & \\ \text { 6-9 } & 3 & & \\ \text { Major crop 1 } & & 44.1 & \\ \text { Maize } & 52 & 22.0 & \\ \text { Cassava } & 26 & 6.8 & \\ \text { Vegetable } & 8 & 4.2 & \\ \text { Water melon } & 5 & 5.9 & \\ \text { Vegetable } & 7 & 14.3 & \\ \text { Others } & 20 & \end{array}$

Source: Field Survey, 2013

Figure 1 shows the various crops cultivated by the respondents in the study area. The study reveals that crop farmers in Oke-Ogun area of Oyo state were predominantly into food crop production. The study reveals that of the major crops indicated by the respondents, maize was the most prominently $(44.1 \%)$ grown in the study area, followed by cassava $(22.0 \%)$. This suggests that the climatic and soil condition of Oke-Ogun, favour most the cultivation of maize and cassava. This further revalidates the fact that Oke-Ogun is the food basket of Oyo state as posited by Sangotegbe et al., (2012). This is because maize and cassava form the main food component in many households in the Oyo state.

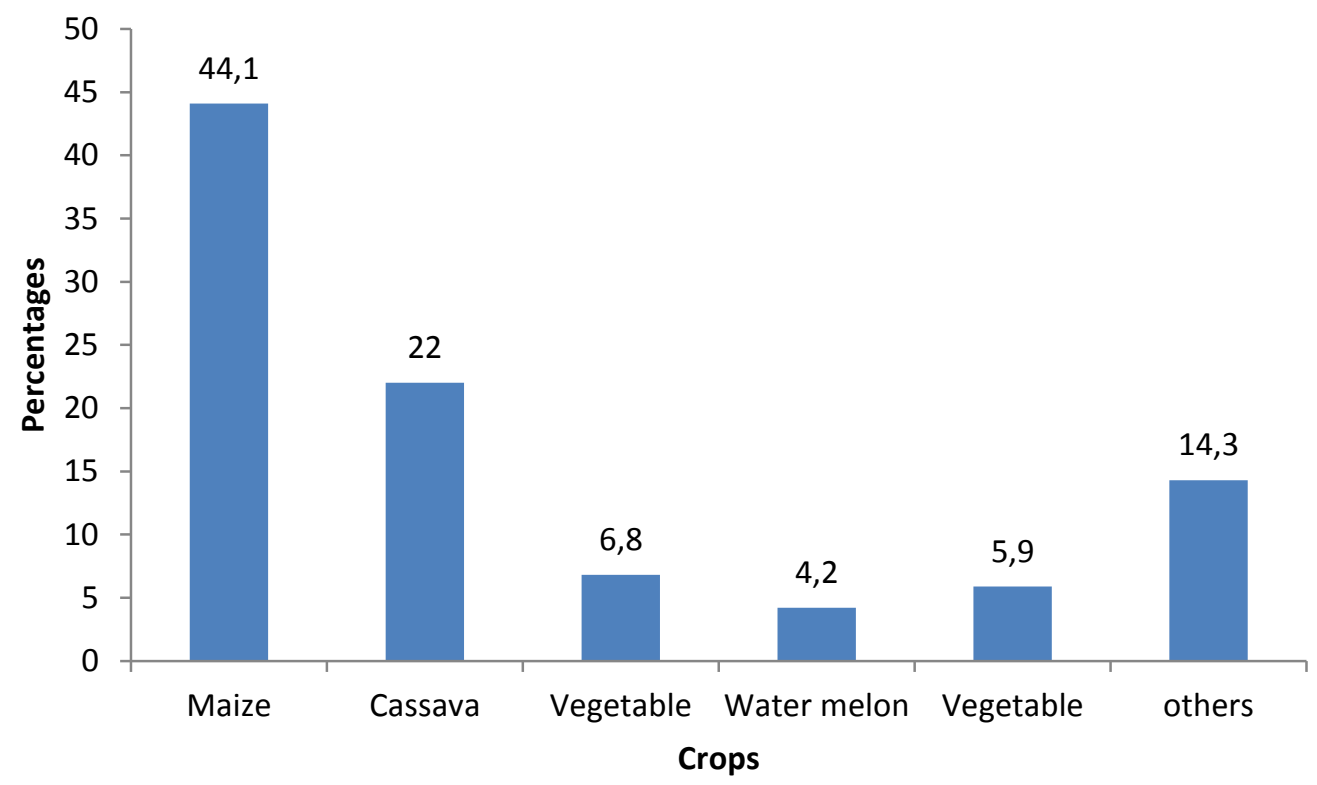

Figure 1. Distribution or respondents based on major crops grown

Source: Field Survey, 2013

\section{Constraints to use of the e-wallet-powered GESS}

GESS, through the e-wallet platform is not without associated challenges. The study (Table 2) identified the various constraints to the e-wallet powered GESS in the study area. Findings reveal that 
majority (66.9\%) of the respondents indicated non commitment of the ADP was a major constraint of the scheme, while $38.1 \%$ believed that, the distance covered from their home to the redemption office was too long. Also, the findings reveal that some $(28.8 \%)$ of the respondents claimed that the interference in the operation by influential people is a hindrance to the success of the scheme. From the table, it can be inferred, that all other constraints facing the scheme which included long queues at the redemption centres, coming late of mobile alert, sharp practices and long distances covered from home to redemption stations are traceable to either non-commitment of the ADP or low extension agentsfarmer ratio, or both. These findings partly agree with Adebo (2014), who identified similar constraints to the implementation of GESS. Osinowo (2012) also identified institutional, political, managerial, economic and social issues as the serious challenges and constraints facing the sustainability of the Agricultural Transformation Agenda and the GESS of the Federal Republic of Nigeria.

Table 2. Constraints to the use of e-wallet platform of the GESS

\begin{tabular}{llll}
\hline \multicolumn{1}{c}{ Statements } & $\begin{array}{l}\text { Not } \\
\text { constraint }\end{array}$ & $\begin{array}{l}\text { a } \\
\text { constraint }\end{array}$ & $\begin{array}{l}\text { Severe } \\
\text { constraint }\end{array}$ \\
\hline Stress farmers go through in order to get inputs & 22.9 & 54.2 & 22.0 \\
Long queues at the redemption centers & 19.5 & 63.6 & 16.9 \\
High transaction cost incurred by farmers & 37.3 & 58.5 & 4.2 \\
Sharp practice by input distributors/dealers & 36.4 & 48.3 & 15.3 \\
Late supply of inputs & 15.3 & 56.8 & 28.0 \\
Long distance covered from home to redemption & 19.5 & 42.4 & 38.1 \\
Interference in operation by govt agent/officials & 31.4 & 37.3 & 31.4 \\
Mobile alert message come late & 34.7 & 50.0 & 15.3 \\
Non commitment of ADP staff of GESS & 12.7 & 20.3 & 66.9 \\
Less quantity of agro-inputs allocation & 16.9 & 50.0 & 33.1 \\
Agro-inputs supplied are not suitable for & 56.8 & 28.8 & 14.4 \\
production in the operation by influential people & 16.1 & & \\
Interference in the & 55.1 & 28.8 \\
\hline
\end{tabular}

Source: Field Survey, 2013

\section{Attitudes of crop farmers towards the e-wallet platform of the GESS}

The study (Table 3 ) reveals that $50.0 \%$ and $61.0 \%$ respectively of respondents strongly agreed that telephone method is very suitable to access input for farmers and that e-wallet will blossom more with more commitment from ADP staff and. Also, almost half of respondents strongly agreed that the modus operandi of e-wallet is suitable for the rural farmer (48.5\%) and that e-wallet has instilled farmers' interest in further agricultural programmes (49.2\%). This implies that crop farmers have good attitudinal disposition towards the Scheme in the study area. The study further reveals that a sizeable number of respondents agreed that GESS's e-wallet platform has reduced corruption in input supply (58.5\%). This implies that e-wallet platform has been able to address the problems of corruption in the supply of agricultural inputs, and thereby achieving one of the main aims for which the scheme was launched. The findings further reveal that majority of farmers agreed that success would be achieved in developing agriculture, if e-wallet is sustained. This is another pointer to the fact that the e-wallet platform has been able to address farmers' needs properly that they now have some levels of trust and confidence in government agricultural programmes. This has a lot of far-reaching effects on sustained food availability, and in no time, the issue of food insecurity would have been reduced to the barest minimum. The study reveals that a sizeable number (50.0\%) agreed that more farmers will emerge if GESS's ewallet implementation is extended

Also, the study reveals that majority $(58.5 \%)$ disagreed that -the e-wallet platform has not really eliminated intrusion of supplied agro-inputs by different dealers and that the scheme is only beneficial to selected group of farmers because they are influential (47.5\%), and 39.0\% that although GESS is beneficial, it has wasted a lot of resources that outweighed the gains. The findings are pointers to the fact that majority of the farmers have favourable attitude to the programme in the study area. This suggests that the scheme will fulfil the various promises and prospects accruable, when the full 
implementation finally ensues. Tiri et al., (2014) had highlighted the prospects, positing that the scheme will serve as a stimulus for modern economy and enhance rural income. If this policy frame work is well pursued, it will also reduce Nigeria food import bill and stimulate agricultural export. Indeed it will stimulate the growth of the agricultural sector and by extension, the economy.

Table 3. Distribution of respondents based on their attitudes to the e-wallet platform of the GESS

\begin{tabular}{|c|c|c|c|c|c|}
\hline Statements & SA & $\mathbf{A}$ & $\mathbf{U}$ & $\mathbf{D}$ & SD \\
\hline $\begin{array}{l}\text { e-wallet platform will end up in failure as past } \\
\text { programme }\end{array}$ & 67.8 & 27.1 & 1.7 & 0.8 & 2.5 \\
\hline $\begin{array}{l}\text { Telephone method is very suitable to access input for } \\
\text { farmers }\end{array}$ & 50.0 & 44.9 & 3.4 & 1.7 & 0.0 \\
\hline $\begin{array}{l}\text { GESS's e-wallet platform has reduced corruption in } \\
\text { input supply }\end{array}$ & 34.7 & 58.5 & 6.8 & 0.0 & 0.0 \\
\hline $\begin{array}{l}\text { The modus operandi of e-wallet is suitable for the rural } \\
\text { farmer }\end{array}$ & 48.5 & 46.6 & 4.2 & 0.8 & 2.5 \\
\hline $\begin{array}{l}\text { Success would be achieve in developing agriculture if e- } \\
\text { wallet is sustained }\end{array}$ & 30.5 & 68.5 & 6.8 & 3.4 & 0.8 \\
\hline $\begin{array}{l}\text { Benefits derived from the GESS's e-wallet is not worth } \\
\text { time invested in it }\end{array}$ & 22.9 & 24.6 & 5.1 & 30.5 & 16.9 \\
\hline $\begin{array}{l}\text { e-wallet adequately address farmer's inputs needs, } \\
\text { without much stress }\end{array}$ & 16.9 & 2.0 & 26.3 & 26.3 & 8.5 \\
\hline $\begin{array}{l}\text { Agro-input distribution timing is appropriate with e- } \\
\text { wallet }\end{array}$ & 24.6 & 31.4 & 16.9 & 18.6 & 8.5 \\
\hline GESS could have been better if farmers were consulted & 33.1 & 43.2 & 8.5 & 9.3 & 9.5 \\
\hline $\begin{array}{l}\text { Poor feedback opportunity makes the e-wallet platform } \\
\text { uninteresting to me. }\end{array}$ & 23.7 & 33.9 & 20.3 & 15.3 & 6.8 \\
\hline $\begin{array}{l}\text { E-wallet has instilled farmers' interest in further } \\
\text { agricultural programmes. }\end{array}$ & 49.2 & 37.3 & 4.2 & 5.9 & 3.4 \\
\hline $\begin{array}{l}\text { GESS is though beneficial, but has wasted a lot of } \\
\text { resources that outweighed the gains. }\end{array}$ & 19.5 & 8.5 & 1.7 & 39.0 & 31.4 \\
\hline $\begin{array}{l}\text { E-wallet will blossom more with more commitment from } \\
\text { ADP staff and Cellulants. }\end{array}$ & 61.0 & 28.0 & 6.8 & 1.7 & 2.5 \\
\hline $\begin{array}{l}\text { More farmers will emerge if GESS's e-wallet } \\
\text { implementation is extended }\end{array}$ & 41.5 & 50.0 & 4.2 & 3.4 & 0.8 \\
\hline $\begin{array}{l}\text { General neglect of farmers perception is a major } \\
\text { impediment for a successful e-wallet scheme }\end{array}$ & 28.0 & 35.6 & 23.7 & 8.5 & 4.2 \\
\hline $\begin{array}{l}\text { All services provided by e-wallet platform are beneficial } \\
\text { to all individual farmers }\end{array}$ & 18.6 & 23.7 & 16.9 & 33.9 & 6.8 \\
\hline $\begin{array}{l}\text { E-wallet platform has not really eliminated intrusion of } \\
\text { supplied agro-inputs by different leaders }\end{array}$ & 16.1 & 8.5 & 12.7 & 58.5 & 4.2 \\
\hline $\begin{array}{l}\text { The scheme is only beneficial to selected group of } \\
\text { farmers because they are influential }\end{array}$ & 17.8 & 8.5 & 4.2 & 47.5 & 22.0 \\
\hline $\begin{array}{l}\text { The e-wallet has achieved only so small than the general } \\
\text { expectation from the government }\end{array}$ & 3.4 & 6.8 & 44.1 & 44.9 & 0.8 \\
\hline $\begin{array}{l}\text { The too many success noise about e-wallet is truly } \\
\text { nothing but propaganda. }\end{array}$ & 12.7 & 10.2 & 9.3 & 60.2 & 7.6 \\
\hline
\end{tabular}

$\mathrm{SA}=$ Strongly Agree, $\mathrm{A}=$ Agree $=\mathrm{A},(\mathrm{U}=$ undecided, $\mathrm{D}=$ Disagree and $\mathrm{SD}=$ Strongly Disagree

Source: Field Survey, 2013

The overall attitude of the farmers was represented in two categories of favourable and unfavourable (Table 4). This was determined as the mean attitude scores was computed and used as the benchmark, such that respondents whose scores are below the mean attitude scores were categorised in 'unfavourable', while those whose scores are equal or greater than the mean were categorised in' 
favourable'. Table 4 indicates that $56.8 \%$ of the respondents showed favourable attitude towards ewallet platform, while only $43.2 \%$ had unfavourable attitude. This shows that majority of the respondent have favourable attitude towards the e-wallet platform of the GESS scheme. Favourable attitude of farmers towards GESS allows them have access to improved agricultural input as offered by the scheme. This is expected to bring immediate benefits to farmers in terms of improved productivity and food security, while it also helps improve agriculture, food security situation and national economy.

Table 3. Respondents' overall attitudes towards the e-wallet platform of the Growth Enhancement Support Scheme (GESS) for accessing inputs

\begin{tabular}{llll}
\hline Attitude & Score & f & \% \\
\hline Favourable & $64-74$ & 67 & 56.8 \\
Unfavourable & $51-63$ & 51 & 43.2 \\
\hline
\end{tabular}

Source: Field Survey, 2013

\section{Test of hypotheses}

Hypothesis 1: There is no significant relationship between the respondent's socio economic characteristics and their attitude towards the e-wallet platform of the GESS.

Table 5 shows that there is significant relationship between the years of farming of the sampled respondents and their attitude towards the e-wallet platform of the GESS. Likewise there is a significant relationship between respondents' education and their attitude towards the GESS. However there is no significant relationship between respondents' age, size of farm land and their attitude towards GESS. This is against the findings of Ogunsumi (2011) whereas age and farm size showed significant relationship with farmers' adoption behaviour towards improved agricultural practices. It however agrees with the findings of Igodan et al., (1997) and Angba (2000), which revealed that increasing farm size does not necessarily result in positive adoption behaviour.

Table 5. Chi - square analysis of farmers' personal characteristics and attitude the e-wallet platform

\begin{tabular}{lllll}
\hline Variables & df & -value & p- value & Decision \\
\hline Age & 4 & 1.544 & 0.819 & Not significant \\
Years of farming & 4 & $* 11.278$ & 0.024 & Significant \\
Size of farmland & 3 & 1.945 & 0.584 & Not significant \\
Marital status & 3 & 5.987 & 0.112 & Not significant \\
Religion & 2 & 1.602 & 0.449 & Not significant \\
Education & 3 & $* 10.876$ & 0.012 & Significant \\
\hline
\end{tabular}

Source: Field Survey, 2013

Hypothesis 2: There is no significant correlation between constraints and attitudes towards the e-wallet platform of the GESS.

Table 6 shows that there was significant correlation between respondent's constraints and their attitude towards the GESS. The implication is that constraints faced by respondents play a significant role in influencing the attitude of farmers towards the e-wallet platform of the GESS. This agrees with the findings of Nweke et al., (2002) and Teklewold et al., (2006) that there are constraints to adoption of agricultural innovations in rural farming communities. In some instances, farmers reject some of the development programmes due to cultural background and inhibitions due to past bureaucracy faced and elite capture of previous schemes.

Table 6. PPMC analysis of farmers' constraints, awareness and attitude towards GESS

\begin{tabular}{llccc}
\hline Variables & $\mathrm{N}$ & $\mathrm{r}-$ value & $\mathrm{p}-$ value & Decision \\
\hline Constraints & 118 & -0.303 & $0.001 *$ & Significant \\
\hline
\end{tabular}

Source: Field Survey, 2013 


\section{Conclusion and recommendations}

The government over time had invested into agricultural promotional programme and agricultural support scheme leading to development and dissemination of various policies to improve agricultural production, consequently leading to food security of the nation. The success or otherwise of such programmes are often dependent on the behaviour of the farming population towards them. Findings from this study have shown that majority of the respondent have favourable attitude towards the ewallet platform of the GESS. This is expected to translate into improved adoption of agricultural technologies and productivity of crop farmers in Oke-Ogun area, renowned for intense food production in south western Nigeria. This is in spite of the constraints faced by the as revealed by the study. From the findings of the study, the following recommendations are necessary for a more sustainable GESS and similar future programmes.

1. Government should support in promoting GESS by recruiting more ADP workers and reinforcing the existing ones so as to ensure adequate contact with the farmers, as this will facilitate prompt redemption of agricultural inputs.

2. The agencies involved in the GESS should ensure that only good quality fertilizer and other agricultural inputs are made available to the farmers, as this will not only help win the trust of the farmers on government programmes, but will also help guarantee optimal agricultural productivity.

3. Establishment of more redemption centre to stop the rigor of long queue and reduce long distance covered before accessing the centre should be ensured.

\section{References}

Adebo, GM (2014) Effectiveness of E-Wallet Practice In Grassroots Agricultural Services Delivery In Nigeria A Case Study Of Kwara State Growth Enhancement Support Scheme. Journal of Experimental Biology and Agricultural Sciences, Vol. 2, p 4.

Adesina A (2013) Honorable Minister of Agriculture and Rural Development, Federal Republic of Nigeria, Governor from Nigeria, at the 36th Session of the IFAD Governing Council

Akinbile, LA \& Odebode, SO (2002) Determinants of farmers use of sustainable conservation practices in Osun State, Nigeria. Challenges of organic farming and sustainable land use in the tropics and subtropics (http:www.tropentag.de/2002/abstracts/links/akinbile-nfaxzey7.pdf).

Akinbile, LA (2007) Social Impact of Limestone Exploitation in Yewa North Local Government Area of Ogun State, Nigeria. Pakistan Journal of Social Science Vol. 1, pp. 107-111.

Angba, A.O. (2000) Determinant of sustained use of selected technologies recommended to farmers by Cross River State Agricultural Development Programme (ADP).Unpublished Ph.D Thesis, University of Ibadan, Nigeria.

Central Bank of Nigeria (2003) Statistical Bulletin.

Ezeh Ann Nnenna (2013) Access and application of information and communication technology (ICT) among farming households of south east Nigeria.Agriculture and Biology Journal of North America. doi: 10.5251/abjna.2013.4.6.605.616

Federal Ministry of Agriculture and Rural Development Abuja, Nigeria (2011) Agricultural Transformation Agenda: We will Grow Nigeria's Agricultural Sector. Available on

http://www.unaab.edu.ng/attachments/Agricultural\%20Transformation\%20Blue\%20 rint.pdf accessed on March $25,2014$.

FMARD (2012) Nigeria's Agricultural Policy. Federal Republic of Nigeria Federal Ministry of Agriculture and Rural Development, Agriculture in Nigeria: New policy Thrust.

FMAWR\&D (Federal Government of Nigeria) (1989) Agricultural Policy for Nigeria Federal Ministry of Agriculture, Water Resources and Rural Development FMAWR\&D, Lagos.

Idachaba FS (2013) Food security in Nigeria: Challenges under democratic dispensation, 18th ARMTI annual lecture, Ilorin. 
Igodan, C.O. Ohaji, P.E and Ekpere, J. A. (1997) "Factors Associated with the Adoption of Recommended Practice for maize production in the Kanji Lake Basin of Nigeria, "Agricultural Administration and Extension Vol 29, pp. 1-8. doi: 10.1016/0269-7475(88)90013-X

Jagdish, B (1996) The Economics of underdeveloped countries. Aukland: McGraw-Hill. Ondo State Agricultural Development project. 1995, Progress Report on Programme performance', pp. 4-31.

Nweke, FI, Spencer DSC \& Lyman JK (2002) The Cassava Transformation Africa's Best-Kept Secret, East Lansing: Michigan State University Press. doi: 10.5860/choice.39-6428

Ogundari, K. \& SO, OJO (2007) An examination of technical, economic and allocative efficiency of small farms: the case study of cassava farmers in Osun state of Nigeria, Bulg. J. Agric. Sci., Vol. 13, pp. 185-19.

Ogunsumi , LO (2011) Factors affecting sustained use of agricultural technologies: Case of cassava farmers in Southwest, Nigeria. Agriculture and Biology Journal of North America, Vol. 2, No. 1, pp. 23-28 doi: 10.5251/abjna.2011.2.1.23.28

Osinowo, OA (2012) Agricultural transportation in a deregulated economy: The Role of livestock sub-sector. Proceedings of the 46th Annual Conference of Agricultural Society of Nigeria, Held at Bayero University, Kano, p4

Pulitzer (2012) Transforming Traditional Agriculture in Africa', Paper at Joint Session in Yale: Yale University Press

Sangotegbe NS, Odebode SO, \& Onikoyi MP (2012) Adaptation strategies to climate change by food crop farmers in Oke-Ogun area of South Western Nigeria. J Agric Ext, Vol. 16, No. 1, pp. 119-131. doi: 10.4314/jae.v16i1.12

Signal Alliance (2014) ERP FOR THE AGRICULTURE SECTOR IN NIGERIA.Transforming Big Data into Big Value in Agriculture Industry.Retrieved from http://www.slideshare.net/signalalliance/erp-for the agriculture-innigeria accessed on April 23, 2014.

Teklewold H, Dadi L, Yami A, \& Dana N (2006) Determinants of adoption of poultry technology: a doublehurdle approach. Livestock Research for Rural Development, Volume 18 article \# 40, Retrieved July 21, 2014, from http://www.cipav.org.co/lrrd/lrrd18/3/tek118040.htm

Tiri, GD, EA. Ojoko, \& A. Aruwayo (2014) Growth Enhancement Support Scheme (GESS) and the Challenges of Food security in NIGERIA: A Review. Asian Research Publishing Network. www.arpnjournals.com 